\title{
Zinloos zwartepieten over de reïntegratiemarkt
}

\author{
Column
}

Kees Wevers en Joost van Genabeek*

De afgelopen tijd hebben berichten in de media over verspilling van reïntegratiegelden de reïntegratiemarkt in een kwaad daglicht gesteld. De discussie lijkt een vorm van zwartepieten. Publieke opdrachtgevers verwijten reïntegratiebedrijven, die werklozen en arbeidsongeschikten weer aan het werk moeten helpen, een te geringe kwaliteit of weinig feeling met de vraagkant van de arbeidsmarkt. De bedrijven op hun beurt klagen over te lage subsidies ofwel 'trajectprijzen' en te geringe transparantie bij gemeenten inzake aanbestedingsprocedures. Gemeenten zouden ook nog eens het grootste deel van hun budget besteden aan gesubsidieerd in plaats van regulier werk. Door deze verwijten kan de indruk ontstaan dat investeringen in activering en reïntegratie weggegooid geld zijn. De regering neemt een wat halfslachtige houding aan en lijkt soms meer vertrouwen te hebben in inkomensprikkels voor werklozen of met werkloosheid bedreigde arbeidsgehandicapten. Dit valt ook af te leiden uit de nieuwe WAO- en WW-plannen. In de woorden van het CPB: 'Activering met de stok is effectiever dan met de wortel ${ }^{1}$. Het zwartepietenspel komt mede voort uit een onduidelijke verantwoordelijkheidsverdeling of het afschuiven van verantwoordelijkheden.

Het staat buiten kijf dat het functioneren van de reintegratiemarkt verbeterd moet worden, maar dit is niet alleen zaak voor de reïntegratiebranche. De overheid speelt, ook via lagere overheden en instanties als UWV, een cruciale rol. De overheid kan er niet mee wegkomen te verklaren dat 'men alle vertrouwen heeft dat de markt zijn werk zal doen'. De reïntegratiemarkt is per definitie een 'quasi- markt', een markt die op instigatie van de overheid is ontstaan en waar de overheid ook in vergaande mate de voorwaarden bepaalt waaronder reïntegratiebedrijven dienen te werken. Er gaan veel publieke middelen in om, er zijn belangrijke maatschappelijke effecten in het geding en er bestaat een complexe driehoeksverhouding tussen opdrachtgever, opdrachtnemer en de cliënt, welke laatste niet zelf voor de dienstverlening betaalt. Als bijvoorbeeld de overheid door haar marktmacht no cure, no pay-contracten afdwingt (in de private markt overigens ongebruikelijk bij dienstverlening) oogst men wat men zaait: bulkdienstverlening en terugloop in scholing. Staatssecretaris Van Hoof kan weliswaar met tevredenheid vaststellen dat de gemiddelde trajectprijs is gedaald van 5.000 naar 3.000 euro. Maar het is zeer de vraag of de publieke middelen daarmee ook effectiever worden ingezet.

Met het oog op de toekomst is de reïntegratiemarkt echter te belangrijk voor vruchteloos gekissebis. Onlangs organiseerde de vaste commissie voor Sociale Zaken en Werkgelegenheid van de Tweede Kamer een seminar over de toekomst van arbeidsmarktbeleid en sociale zekerheid. Uiteraard stond daar de reïntegratie van werklozen en arbeidsongeschikten ook centraal. SER-voorzitter Herman Wijffels was van mening dat 'levensloopregelingen' op termijn wel eens essentieel 'participatiecement' zouden kunnen blijken. Henriëtte Prast van de Universiteit van Tilburg en De Nederlandsche Bank gaf originele en praktische tips die meer vliegen in een klap slaan, zoals de moderne variant op gratis schoolmelk. Zij stelde dat schoollun-

* De auteurs zijn medewerkers van TNO Arbeid, Postbus 718, 2130 AS Hoofddorp. 
ches kinderen leren mes en vork te gebruiken en ook nog gezond te eten. De lunches creëren werk in de lokale dienstverlening en geven vrouwen de gelegenheid meer uren te werken. Overheidssubsidie is hier zeer kosteneffectief. Henriëtte Maassen van den Brink van de Universiteit van Amsterdam benadrukte het belang van initieel onderwijs, leer-werktrajecten met een zekere mate van overheidsdwang als belangrijkste middel voor participatie en voor employability gedurende de loopbaan. Peter van Lieshout van de WRR belichtte de ontwikkelingen in Europees perspectief. Nederland doet het zo slecht nog niet ten aanzien van activering en reïntegratie. En in alle landen blijkt ook de moeizame weg naar een effectievere uitvoeringsorganisatie als voorwaarde voor succes te gelden.

Als voorbereiding op het seminar is de commissie van de Tweede Kamer bedolven onder notities van de Planbureaus, sociale partners, WRR en andere organisaties waaronder TNO. ${ }^{2}$ Als er in deze bijdragen al een rode draad te onderscheiden is, dan is het wel dat de nieuwe WAO en WW zeker geen sluitstuk zijn in de hervormingen van de sociale zekerheid. Op de eerste plaats zal er een meer structurele relatie tussen werk(hervatting) en onderwijs en scholing nodig zijn. Hierbij is een zekere dwang tot participatie in welke vorm dan ook onontkoombaar. Ten tweede betekent een solide sociale zekerheid - zeker in de beleving van de burger - een goede kwaliteit van de publieke en maatschappelijke dienstverlening, al wordt deze door private partijen uitgevoerd. Als ontwikkelingspad lijkt het Scandinavische model, waarin een streng activerend arbeidsmarktbeleid wordt gecombineerd met een grote mate van inkomenszekerheid, het meest met de preferenties van de Nederlander overeen te stemmen.

Wat betekent dit alles nu voor de reïntegratiebranche? Het tijdperk van de kale 'trajecten' van luttele duizenden euro's zal ongetwijfeld ten einde lopen. Werkverschaffing (work first), doorstroming en scholing lijken de centrale uitgangspunten te gaan vormen. Het doorbreken van het monopolie van de ROC's (Regionale Opleidingscentra) en de recente voorstellen van de RWI voor participatiebanen (de bijstandsuitkering als loon) wijzen ondubbelzinnig deze kant op. Reïntegratiebedrijven zullen met publiek en privaat geld gaan ondernemen.

Bovenal zal er meer differentiatie komen in vraag en aanbod van de reïntegratiedienstverlening. Zo komt er meer ruimte voor experimenten in regio's, waarbij de risico's gezamenlijk gedragen worden door de (publieke) opdrachtgever en de private (reïntegratie)onderneming. Ook de individuele reïntegratieovereenkomst (iro) zal bijdragen aan de toenemende differentiatie omdat deze ruimte geeft voor sturing door de individuele cliënt. Meer differentiatie in de reïntegratiedienstverlening maakt het bevorderen van transparantie extra belangrijk. Cliënten en opdrachtgevers moeten immers een exit-optie hebben. Zijn zij niet tevreden, dan kunnen ze naar een ander bedrijf. Voor de reïntegratiebedrijven betekent dit dat zij een grotere openheid moeten betrachten wat betreft hun bedrijfsvoering en resultaten dan gebruikelijk is in het bedrijfsleven. Van de kant van de overheden betekent dit het doorzetten van bestuurlijke vernieuwing en 'ontschotting' van beleid (bijvoorbeeld met de nieuwe Wet maatschappelijke ondersteuning). Terugkeer naar volledige publieke uitvoering van de reïntegratiedienstverlening is ondenkbaar, hoe de SUWI-evaluatie in 2006 ook mag uitvallen en al zijn wij in Nederland dol op stelselherzieningen en -discussies.

De mediadiscussie over de vermeende slechte prestaties van de reïntegratiemarkt is eenzijdig en niet zonder risico. Door elkaar de zwartepiet toe te spelen leidt men namelijk de aandacht af van de problematische arbeidsmarktpositie en onvoldoende kwalificaties van een flink deel van de beroepsbevolking. Het toedienen van inkomensprikkels (zoals de criticasters willen) is niet voldoende om mensen op grote schaal aan het werk te krijgen en te houden. Forse bijdragen aan onderwijs, scholing, activering en reïntegratie zijn onontbeerlijk, ook de OECD wijst daarop. De huidige maatschappij moet daarom helaas 'dubbel dokken'. Lacunes uit het verleden dienen gerepareerd te worden en tevens zal er geïnvesteerd moeten worden in de toekomst. Met name door de vergrijzing zal men bij uitstel op termijn duurder uit zijn. 
Zinloos zwartepieten over de reïntegratiemarkt

\section{Noten}

1 Centraal Planbureau (2005). Naar een toekomstig stelsel voor arbeidsmarkt en sociale zekerheid. in: Syllabus Nieuwe Accenten op het Terrein van Werk en Inkomen. Vaste commissie van de Tweede Kamer voor SZW. Den Haag.

2 Vaste commissie van de Tweede Kamer voor SZW (2005). Syllabus Nieuwe Accenten op het Terrein van Werk en Inkomen. Den Haag. 